\title{
The Engraved Pebble from Pavlo-Ochakovskaya Spit
}

\author{
Elena A. Mironova \\ Department of Linguistics and Cross-Cultural Communication, Rostov State University of Economics, Rostov-on-Don, Russia \\ Email: arkova12-14@yandex.ru
}

How to cite this paper: Mironova, E. A. (2021). The Engraved Pebble from Pavlo-Ochakovskaya Spit. Advances in Anthropology, 11, 261-279.

https://doi.org/10.4236/aa.2021.114015

Received: April 28, 2021

Accepted: August 31, 2021

Published: September 3, 2021

Copyright $\odot 2021$ by author(s) and Scientific Research Publishing Inc. This work is licensed under the Creative Commons Attribution International License (CC BY 4.0).

http://creativecommons.org/licenses/by/4.0/

(c) (i) Open Access

\begin{abstract}
The status of the pebble artifacts found on the seashores and banks of the lakes in the sacral places is being discussed intensively in modern archaeology during recent years. Many of suchlike engraved stone sculptures in a shape or with the images of a bear, a bird, an elk/deer, etc. were found in the Urals and Siberia. All finds are connected with the cult places of worship, namely, painted cliffs or petroglyphs. The shamans' burials also were found nearby. This article presents a new find made by the author in summer, 2020 on the Sea of Azov shore, on Pavlo-Ochakovskaya spit-the sandy beach in the Gulf of Taganrog, Rostov-on-Don Region. The shape of this pebble is of the canonized form of an elk/deer head and it looks like the artifacts from: Kazachka-I, the basin of the river Yenisei; Zamostie-2; Podty 1 (Komi Republic) and Mikhailovka-Klyuch (Osinoozersk culture), western Amur region archaeological sites. The previous findings of the similar shape were found not only on the open spaces but also in the archaeological layers. Archaeology still does not have a clear answer to the question of the usage of this kind of artifact. A new find from the Sea of Azov shore has an image of a running deer, which is partially painted and partially engraved. It has an incision marking the muzzle of a deer and very thin lines crossing the deer's body. With the help of comparative study and interdisciplinary approach in this paper, we found out that similar stone sculptures in the shape of an elk/deer head were the markers of the migrated tribes since Paleolithic and can be attributed as the symbols of the Great Goddess-a divinity of mountains, stones and fertility cult widely spread in Eurasia since the Upper Paleolithic.
\end{abstract}

\section{Keywords}

Engraved Pebble, Pavlo-Ochakovskaya Sand Spit, Zoomorphic Shape, Sacral Places, Eurasian Paleolithic Cult, Great Goddess, Interdisciplinary Approach, Culturological Study, Archaeological Data, DNA-Genealogy 


\section{Introduction}

Stone sculptures analysis is a significant source in the sphere of investigating the roots of ancient people's spiritual life and beliefs (Bgazhnokov, 2016). Being found in the archaeological layers and precisely attributed chronologically, they serve as the markers of the specific archaeological cultures (Bocharova \& Zotkina, 2017; Kovalenko, 2015). Still, in modern archaeology, there are more and more artifacts which are being found on the open spaces, namely: on the farm-fields or on the sea-shores and the banks of the lakes in the special, i.e. on the sacral places of worshipping the ancient gods (Serikov, 2012a; Serikov, 2012b). Such finds can be attributed and studied only on the basis of the previously found similar objects, which were discovered in the archaeological sites and in the stratigraphic layers.

With the help of interdisciplinary research namely-the culturological analysis and the comparative study of the findings from archaeological layers-we try to prove the existence of cult objects which were made of stones or pebbles and reflected the idea of fertility in animals' life. This idea and cult were crucial for the survival of the hunters in the Paleolithic (Mironova, 2017a; Mironova \& Shkvarya, 2018). The so-called "bear cult" was widely spread since Paleolithic from Europe to the Far East, from Siberia to Greece (Kotov, 2001; Medvedeva, 2011; Molodin, Oktyabrskaya, \& Chemyakina, 2000). It was reflected on numerous artifacts and, according to the investigations made by Rybakov, B. A. replaced the previous cult of so-called "sky deers-rozanitsy" (women in labor) (Rybakov, 1981). This kind of substitution was traced with the help of visual analysis when it was noted that same stone object has a polyeiconic nature: it reflects a partial image-a head of an elk/deer and at the same time, it has a shape of a fully-figurate bear. All these previously found artifacts rested on the places with specific geophysical features, namely: on the border of two elements-water and soil (sacral for the ancient people beliefs), and sometimes they were accompanied with the burials of shamans (Serikov, 2011).

The new find was also discovered on the suchlike border (tidal waterway)—on the sandy beach of a very specific place which is called Pavlo-Ochakovskaya spit, in the Gulf of Taganrog, Rostov-on-Don Region, Russia. Similar objects from the Urals and Siberia have been analyzed before by archaeologists (Viktorova, 2010; Serikov, 2014). With the help of visual and comparative methods and interdisciplinary study with collecting the culturological and archaeological data, we analyze the shape, the marks of manual processing and specific features on the surfaces of the pebble from the Sea of Azov.

\section{Literature Revision}

Studies concerning ancient fertility cults are numerous and involve not only the fundamental reviews of cult practices (Eliade, 1964; Leroi-Gourhan, 1964) but also the scientific works devoted to the analysis of the cult objects from particular archaeological sites (Gorshunova, 2007; Mellaart, 1965; Okladnikov, 1966, etc.). 
Gimbutas, M. devoted many studies to the cult of Great Goddess depicted in the figurines of birds, frogs, bees and other images (Gimbutas, 1974).

Hierotopia-the science of sacred places in ancient societies is actively developing (Eliade, 1964; Lidov, 2006). This scientific direction is engaged in the study of religious complexes, including very ancient ones, located near notable natural objects—mountains, rocks, rivers, lakes, large trees (Bartsyts, 2010; Sokolova, 2013). The works of scientists-ethnographers, archaeologists of the Urals, Altai, Siberia, and the Far East are devoted to the study of sacred places as products of human activity (Antonova \& Tashak, 2013: pp. 233-236; Garkovik, 2013: pp. 172-177; Ivanov, 2011; Mazhitov, 1977: p. 27, etc.). Khasanova, Z.F. writes about the cult of the bear and the veneration of the mountains among the Bashkirs (Khasanova, 2013: p. 147).

In this article, we will present our own findings of pebble sculptures found in different parts of Eurasia. These are bear/elk pebbles, the shape of which is unified, reproducible and easily recognizable, despite the fact that they were seen at a colossal distance from each other-on the coasts of different seas: the Sea of Azov, the Black Sea and the Adriatic Sea (Mironova, 2015a). These pebbles were located on the border between the two worlds-the world of water and earth, on the surf line, just like other cult pebbles found, for example, in the Urals, on Shaitan Lake (Serikov, 2012b). Some scientists also believed that these pebblessculptures were the repositories for the souls of the dead people (Gorshunova, 2007).

Data on the migrations of an ethnic group that was the ancestor of haplogroups $\mathrm{R}$ and $\mathrm{Q}$, as well as the creator of the so-called "bear cult" (possibly founded this bear cult in the Upper Paleolithic), can be revealed not only by sequencing the paleo-DNA of bone remains of representatives of this ancestral ethnic group, but also by analyzing and comparing artifacts accompanying this ethnic group that reflect a single cult (the cult of the bear-elk), namely, with the help of analysis of the zoomorphic polyeiconic pebbles-sculptures, which have the constant polyeiconic shape: a bear (full-figure image) and an elk (partial image).

Present-day data provided by the founder of DNA-genealogy-Professor Anatoly Klyosov informs that one of the SNIP mutations in the Y-chromosome with the appearance of haplogroups NOP $\sim 48,000$ y.b.p. and P 38,000 y.b.p. during their migration to the east of Southern Siberia, led to the appearance of haplogroup $\mathrm{R} \sim 30,000$ y.b.p. and haplogroup R1 26,000 y.b.p., and then-haplogroup R1a/R1a1 $\sim 20,000 \mathrm{l}$. $\mathrm{n}$. (the time frame between the appearance of R1a and R1al is not defined) and haplogroups R1b 16,000 BP" (Klyosov, 2012: p. 103). Further migrations of two branches of the ancestral haplogroup R1 (descendants of haplo-group R)-haplogroups R1a and R1b were then traced in the works by Klyosov, A. A. and Rozhansky, I. L.: "It should be noted that two fraternal subclades, R1a and R1b, migrated from Central Asia to the west by two different routes. While R1a moved along the southern route from the Altai region through the Himalayas, Hindustan, the Iranian plateau, Anatolia and from Asia Minor to the Balkans 
(Klyosov \& Rozhanskii, 2012), R1b moved along the northern route, from the same region through the Southern Urals, Central Asia, Northern Kazakhstan, the Middle Volga, the Caucasus, and then split into two streams-one moved in a southern direction, the other-in the west (Klyosov, 2012: p. 92)".

The descendants of haplogroup R-R1a, having passed through Asia Minor and the Balkans through millennia in time and thousands of kilometers in space, ended up in the Carpathians, which is confirmed by the presence of a swastika on the ceramics of the archaeological culture of Tripolye-Cucuteni (Ukraine, Moldova-Romania), as well as, possibly, by the iconical image of a female Goddess in a small sculptural forms, the same as at the site of Malta (Siberia, the Baikal Lake region) - the origin of haplogroup $\mathrm{R}$ bearers and by the canonical (polyeiconic) form of the stone sculptures (from pebbles to big boulders) - the bear/elk sculptures.

\section{Methodology}

The conceptual and methodological basis of this study is a combination of different approaches and research methods. In addition, functional and structural methods were used to analyze the actual data. This research synthesizes also a visual study of different archaeological collections data from many sites of Russia-from the Urals and Siberia, as well as from the cult places in Carpathian region, Ukraine. Together with visual study we provide the comparative analysis of the pebble of zoomorphic shape from Pavlo-Ochakovskaya spit comparing it with the pebbles of similar form from the archaeological sites: Kazachka-I, basin the river Yenisei, river Kazachka (Bocharova \& Zotkina, 2017); Mikhaylovka-Klyuch, Western Amur River Region (Kovalenko, 2015: p. 50); Zamostie 2. flint industry of the Upper Mesolithic layer (Lozovsky, 2014: p. 275); Podty 1 (Komi Republic) (Serikov, 2014) and with the same shape objects, but of much bigger size, from the cult places of the Urals (Viktorova, 2010) and the Carpathian (Kugutyak, 2011).

The finding described in this article, was found in the coastal zone, on the border of water and land, that is, in the place of contact of the two elements, in a possible sacred place. So, the ethnological data was also included as a basic element for better understanding the spiritual life of the Stone Age people and the characteristic features of their cult places. The sacred places (or sacred areas, as they are called in the works of Bgazhnokov, B. N. and other Caucasian scientists) are characterized with the combination of two major natural objects: a shallow basin with warm water on the bank of natural reservoir (a lake, a sea-shore) and a mountain nearby. Mountain is an ancient place of worship, because it is a source of water which can come by three ways: from underground (springs), from glaciers (streams, rivers), from rain coming from clouds accumulated around a mountain (Mironova \& Shkvarya, 2018).

From this observation we outline another very significant method of researchthe geo-physical approach and study of the locality (Mironova, 2017a). It means that interdisciplinary approach is the corner stone of the study of such unusual 
objects which are found throughout Eurasia.

\section{Details Revealing the Artificial Origin of the Engraved Pebble from the Sea of Azov}

The pebble was found by the author on the sea-shore of the Sea of Azov, in the place called Pavlo-Ochakovskaya Spit, the Gulf of Taganrog, in June, 2020, on the sandy beach, in two meters from the sea (Figure 1 and Figure 2). It is necessary to mention the different levels of the Sea of Azov in this place, because tides can fill the water area with different volumes of water at different times of the year. In June 2020, the location of the pebble sculpture was exactly two meters from the water's edge.

The bottom of the Sea of Azov in this place is covered with the thick layer of sludge which explains the appearance of suchlike man-made objects (which were left here as votive objects) from time to time on the shore after the storms or gales on the sea.

Despite the fact that this is a very calm place usually, which attracts a lot of parasailing fans, both professional and amateur, the storms happen sometimes, predominantly in winter time. The Sea of Azov despite its small depths is a place where deep underwater plates meet together, thus provoking the turbulence in deep water layers. Meanwhile some parts of Pavlo-Ochakovskaya spit are very calm places where water is calm and with no waves (Figure 3). It could explain the good condition of stone artifacts which have the drawings on the surfaces-

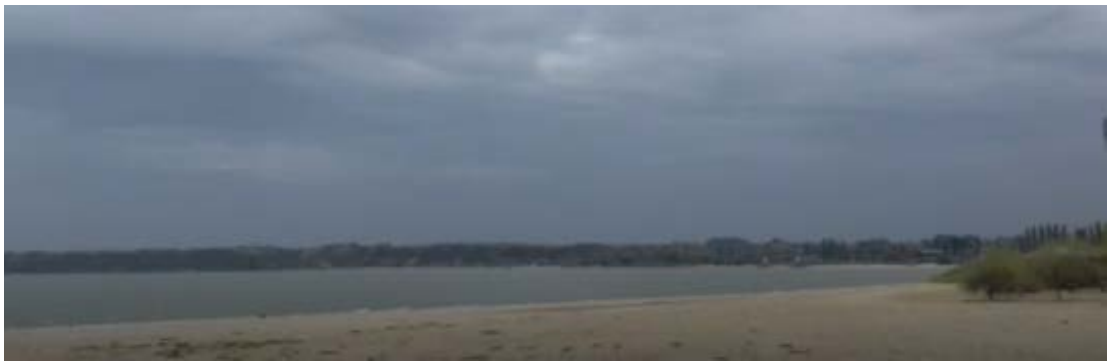

Figure 1. Pavlo-Ochakovskaya spit, the place of engraved pebble discovery (photo by Elena A. Mironova).

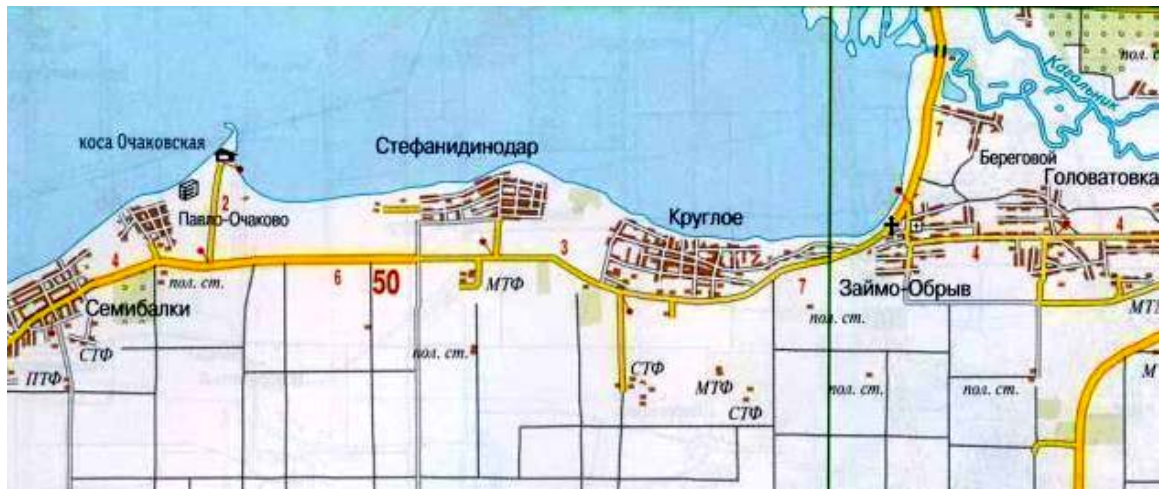

Figure 2. Map with the location of the pebble discovered in the area of recreation centers on the Pavlo-Ochakovskaya spit. 


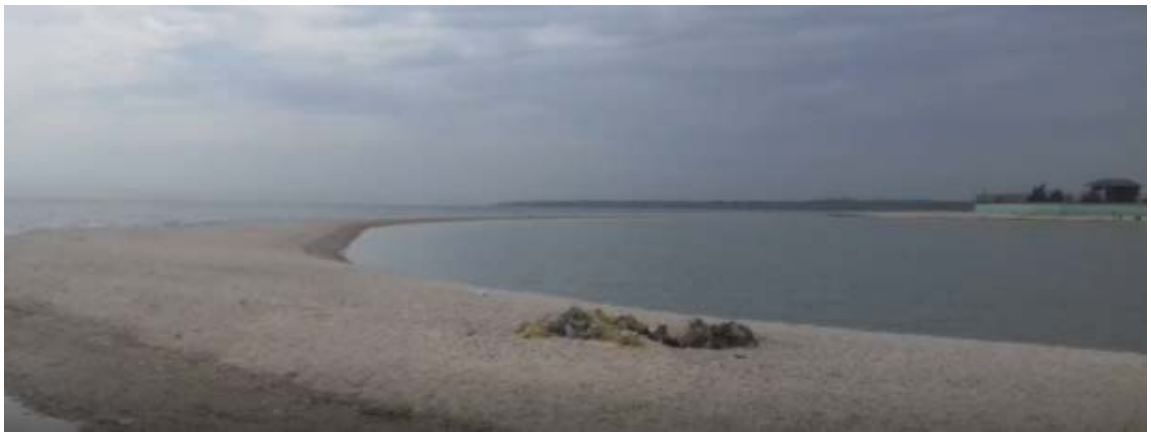

Figure 3. Pavlo-Ochakovskaya spit (other side), which forms here the shallow bay (photo by Elena A. Mironova).

they are not beaten with the waves or moved from one place to another, they simply lie on the sea-shore for centuries. In such calm place we have already found another pebble of zoomorphic shape with a drawing on one of its surface (Mironova, 2016). It means that such kind of investigation must be not only continued but also be widely known in the archaeological circles.

The stone sculpture found here is very small, it is $2.8 \mathrm{~cm}$ length and $2.3 \mathrm{~cm}$ height. It has the shape of a deer head with eyes on both sides. The round hollows (eyes) are done on every side with the help of incisions, not drilling, as they are on different places from the edges of the pebble. The incision on the slightly visible drawing of a running deer is only one and is also hardly visible (this is the line, forming the upper-part of the deer's head). The rest of the lines are done with the help of a special technique which left the dark spots which form the lines-the contour of a running deer. The drawing of a running deer (Figure 4(a) and Figure 5(a)) has a very small round eye and several white lines, made with some acute and very thin instrument (obsidian edge?). These lines cross the body of the running deer (these lines are seen well on Figure 6) and demonstrate probably the ritual "killing" of an animal before hunting.

Similar artifacts were found by Russian archaeologists earlier in the archaeological sites of Siberia, Far East and the Urals (Figures 7-9). One of the example is from the location of the Kazachka I (Figure 7(a)), which is located in the lower reaches of the right tributary of the Yenisei-the Kan River, namely, in the mouth of its right tributary-the Kazachka River, on the above-floodplain terrace (Bocharova \& Zotkina, 2017). This product made of graphite with drilled biconic holes, as a result of dating according to paleo magnetic data, was assigned to the range of 11,004 - 11,080 years ago. Bocharova, E.N. and Zotkina, L.V. describe this artifact as follows: "Only six graphite finds were recorded in the layer, one of them with traces of processing. The latter is a sub-triangular object in plan, decorated with sanding and two holes: one is broken off at the distal end of the object, the second is through. No such items, which could be classified as small plastics, were found on the location and nearby objects. The analysis of the archaeological literature also did not give results in the search for analogies for neighboring territories" (Bocharova \& Zotkina, 2017). 


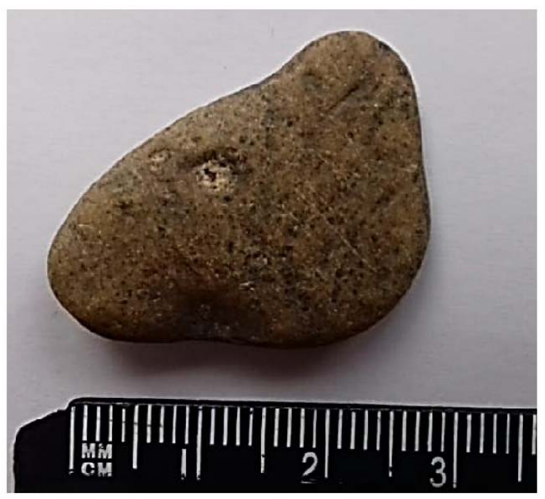

(a)

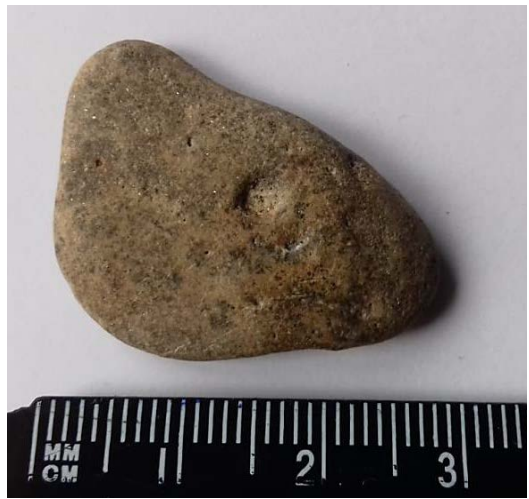

(b)

Figure 4. (a) and (b) Two sides of the finding-a zoomorphic stone sculpture in the shape of a deer/elk head (with eyes on both sides) with a drawing of another animal-a figure of a running deer (find and photo by Elena A. Mironova).

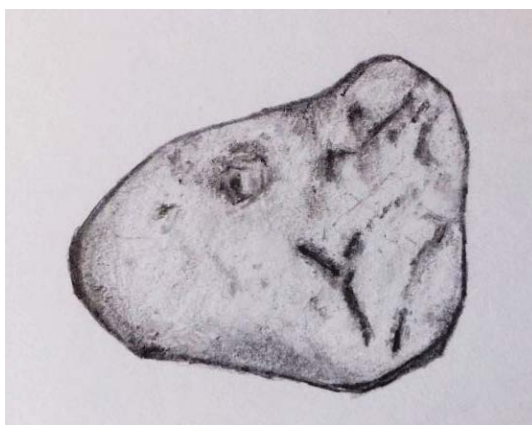

(a)

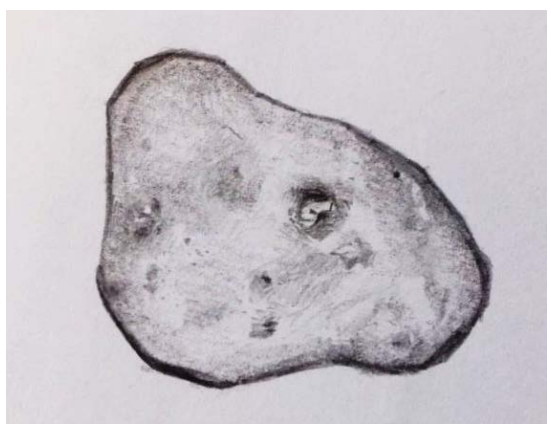

(b)

Figure 5. (a) The drawing of a finding (a zoomorphic stone sculpture in the shape of a deer/elk head with partially engraved and partially drawn deer on this side; (b) other side of the finding (drawing by Amina Safina).

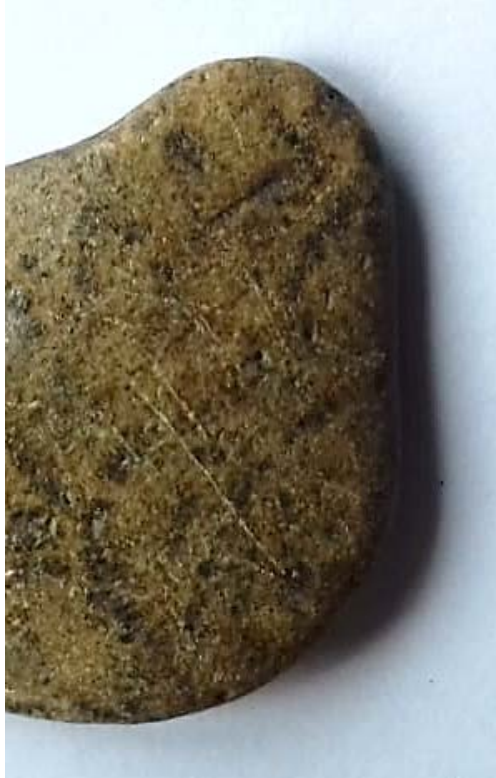

Figure 6. The ancient drawing of a running deer incised across the body with very thin cuts (photo by Elena A. Mironova). 


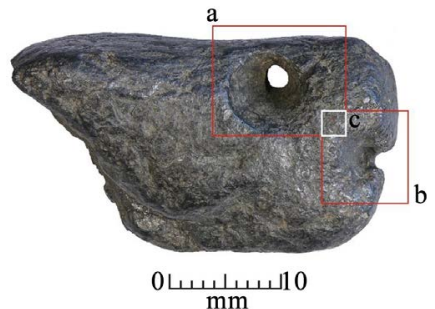

(a)

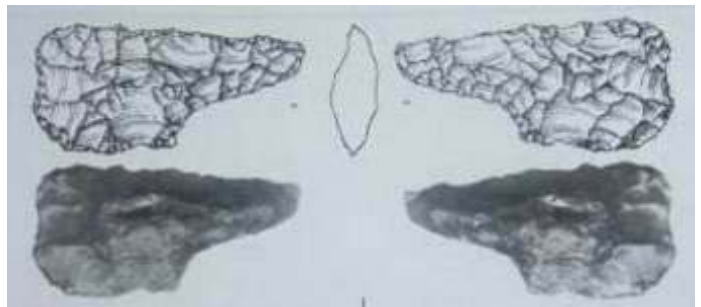

(b)

Figure 7. (a) An artifact from the excavations at the location of Kazachka-I, the basin of the river Yenisei, Kazachka River (Bocharova \& Zotkina, 2017); (b) a pebble in the form of a bear from the site of the Osinoozersk culture, Mikhailovka-Klyuch, Western Amur region (Kovalenko, 2015: p. 50).

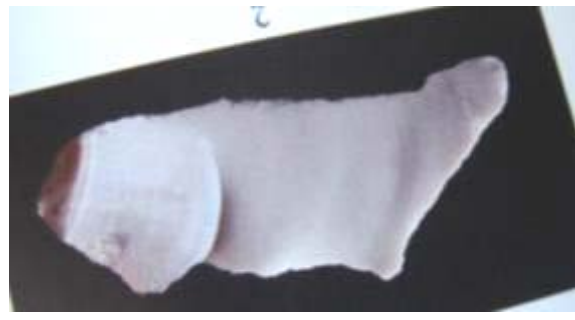

(a)

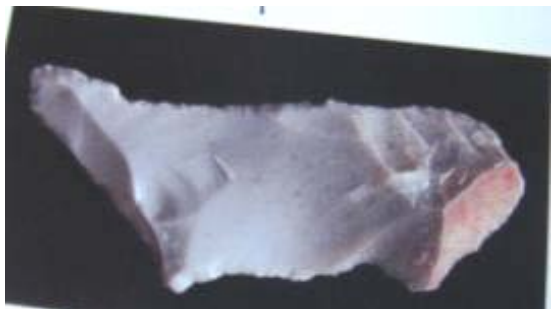

(b)

Figure 8. Stone sculpture, Podty 1 (Komi Republic) with the correct page spread: (a) a full-figure image of a polar bear with its head raised; (b) a partial image of the head of an elk (Serikov, 2014).

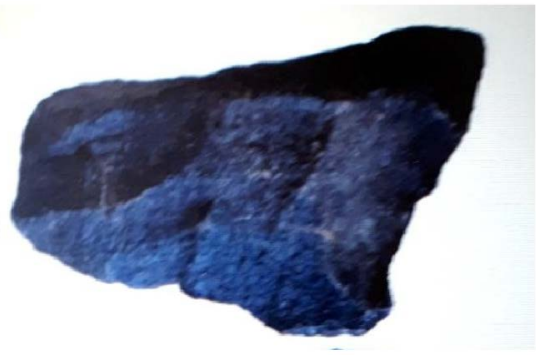

(a)

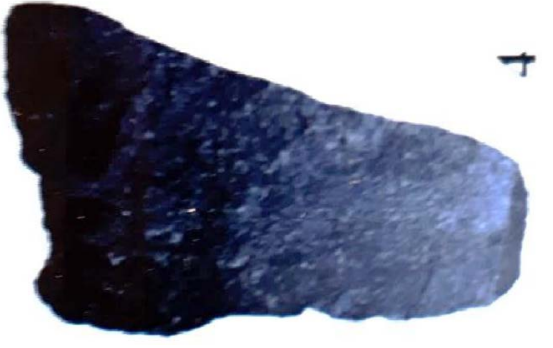

(b)

Figure 9. The find from Kaftar Kouh of Ferdous, Southern Khorasan, Iran-crude flake (Sadraei et al., 2019: p. 118), presumably of the same type and meaning as the finds from Podty 1 (Komi Republic), Mikhailovka-Klyuch, Western Amur region and other.

The authors point to numerous linear traces on many parts of the object made of graphite from the location of Kazachka-I, which, according to a number of signs, are artificial (Figure 7(a)). However, despite the conducted traceological analysis, archaeologists still find it difficult to make a guess about the function of this object: "We can conclude that the object under study was not used as a pendant or button. However, the revealed numerous linear traces, scratches, which are fixed with the naked eye, may indicate other functions of this object" (Bocharova \& Zotkina, 2017).

The zoomorphic pebbles are the kind of the artifacts, acknowledged by archaeologists thanks to the numerous finds in the Urals, Altai and Siberia. They 
are found either in the burials or on the cult areas, on the border between two elements: water and ground (Serikov, 2011: p. 14). Suchlike example is a pebble in the shape of a bear (Figure 7(b)) which was reported by S.V. Kovalenko (Kovalenko, 2015: pp. 41-55). It was discovered on the multi-layer site of Osinoozerskaya culture (this is a culture of the final stage of the Neolithic on the territory of Western Amur river region), namely, in Mikhailovka-Kluch, Blagoveschenskii region. According to Kovalenko, S. V. a sample of a retouched sculpture was found at the site. It was made in a manner characteristic of the Osinoozero culture namely, in the technique of double-sided fine-grained retouching, which was interpreted as an image of a bear: "A flake of a material that is defined as opal was used. The facets were removed from both sides in such a way as to emphasize the individual details of the exterior of a completely recognizable animal: its muzzle and chest, underbelly and back with a shoulder hump." Bifacial processing turned the initial stone into a miniature round sculpture. The absence of any traces of the use of this artifact further indicates the non-utilitarian nature of this artifact (Kovalenko, 2015: p. 44).

The stone sculpture from the archaeological site Podty 1 (Komi Republic, Russia) has the same shape, namely, the partial image of a white bear with a head risen (Figure 8(a)) and at the same time it has another look: the partial image of an elk head - with a retouched ear and elongated muzzle (Figure 8(b)).

Not only has the region of Siberia, Far East and the Urals provided with these artifacts, but also the deserted areas of Iran. In particular, the new research made by a group of Iranian archaeologists (Sadraei et al., 2019) revealed very interesting finds in Southern Khorasan, namely, the Paleolithic instruments in Kaftar Kouh of Ferdous. Among the instruments dated by Paleolithic there was a stone sculpture which looks like the a forehead described artifacts (Figure 9(a) and Figure 9(b)).

According to the authors, these artifacts were discovered near the dry lake and were attributed to the Middle Paleolithic period with mentioning the necessity to explore this region in future for more precise periodization and attribution (Sadraei et al., 2019: p. 122).

The artifacts of this kind are being found on the so-called "sacral areas" (Bgazhnokov, 2016), namely, on the border of two elements: water and land. Very often the burials of shamans are found nearby (Serikov, 2011: pp. 145-150). It means that the thorough analysis of the landscape should be made every time upon finding the pebbles/stones/boulders of this shape, as they could mark the presence of sacred areas in the ancient times, which are not obvious now since the climate changed (dry lake as in case with Kaftar Kouh of Ferdous, Southern Khorasan, Iran).

At present big water reservoirs can provide with look-alike artifacts. The author of this article also found suchlike stone sculptures before (Mironova, 2015a; Mironova, 2015b; Mironova, 2016; Mironova, 2017b)—on the banks of the Sea of Azov (Rozhok village, The Taganrog Gulf), the Black Sea (Sochi) and the Adriatic Sea (Rabac, Chroatia) (Figure 10 and Figure 11). 


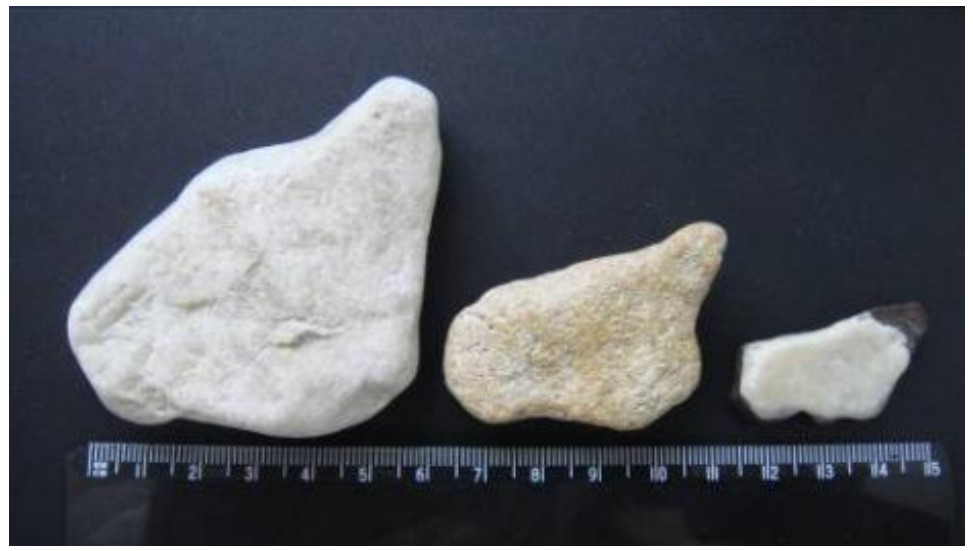

Figure 10. On the left-a pebble sculpture from Rabac (Croatia) - an image of a deer with its head turned to the left; in the middle-a sculpture from the coast of the Sea of Azov (Rozhok village, the Taganrog Gulf) — an image of a polar bear with its head raised, facing to the right; on the right-a two-layer sculpture from the Black Sea coast (Sochi) - an image of a reindeer on the white side (quartz) with its head turned to the left (finds and photo by Elena A. Mironova).

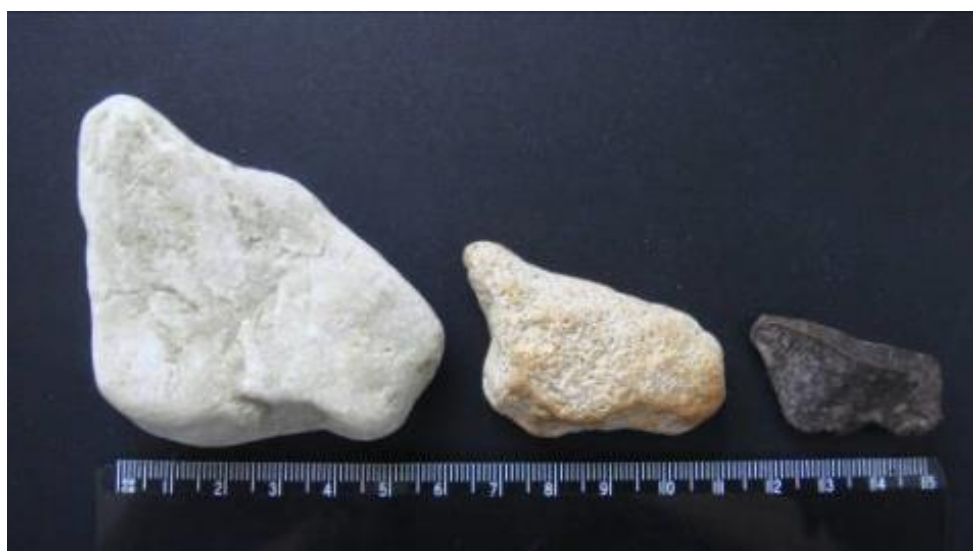

Figure 11. The reverse side of the three pebble sculptures: on the left-a pebble sculpture from Rabac (Croatia) — an image of a bear with its head raised, facing to the left, and the image of an doe with its head turned to the right (there is a characteristic submandibular recess, an ear and a recess for the eye); in the middle-a sculpture from the coast of the Sea of Azov (Rozhok village, The Taganrog Gulf) — an image of an elk/reindeer with its head facing to the right (the ear, submandibular recess is profiled and traces of five blows forming the lower jaw are seen); on the right-a sculpture from the Black Sea coast (Sochi) - an image of an animal on the dark side of the stone, similar in silhouette to a polar bear, with its head raised, facing to the left (finds and photo by Elena A. Mironova).

Recently discovered stone sculpture of a big size happened by chance-while observing the photos made by the travelers, who visited Costa-Brava sea line. Near the town Palamos there are many rocky capes. On one of them there is a big boulder which has a shape of a deer head. Surprisingly, it has a hole in a place which could be served for the "eye" (Figure 12, Figure 13(a)). This stone looks exactly like the one in the Carpathians-on one of the sacral places discovered by the team of Ukrainian scientists in 2011 (Kugutyak, 2011) (Figure $13(\mathrm{~b}))$. 


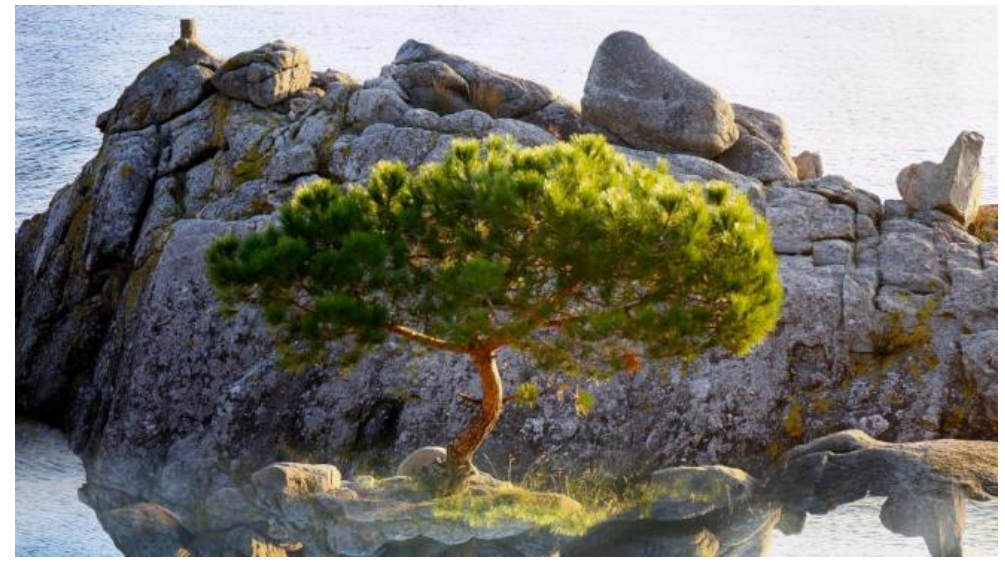

Figure 12. A possible sacral place with a zoomorphic boulder and a throne to the right (Cala s'Alguer, Palamós, Costa Brava, Spain).

https://windows10spotlight.com/images/345828098e0099525e820d90bebc6269

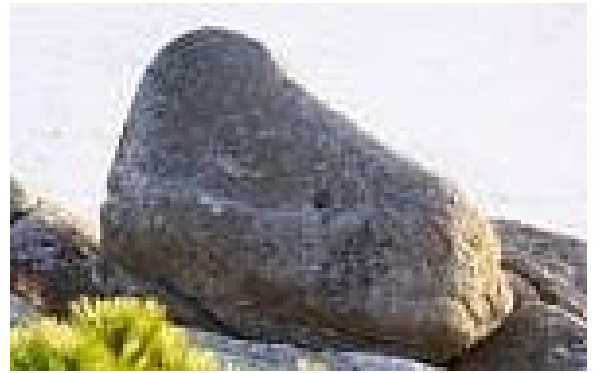

(a)

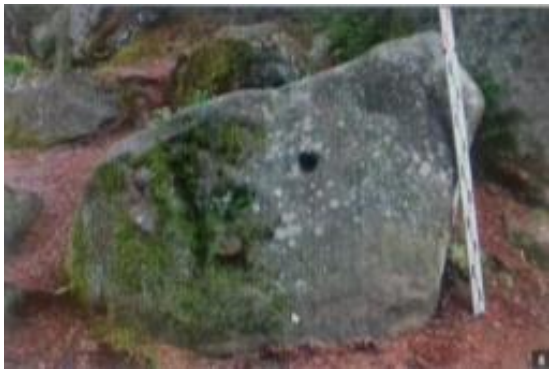

(b)

Figure 13. (a) a magnified image of the stone in the shape of an elk/deer on the coast line near Palamos (Cala s'Alguer, Palamós, Costa Brava, Spain),

https://windows10spotlight.com/images/345828098e0099525e820d90bebc6269; (b) a stone in the form of a polyeiconic sculpture-the head of an elk/deer and the body of a bear, the Carpathians, the village of Dora (Kugutyak, 2011: p. 187).

Nearby there are remains of an Iberian settlement which was located on the high cape, from which the surroundings (the coast, the forest, the nearest capes) were seen very distinctly. This location provided the domineering position over other settlements.

The boulder in a shape of a deer/elk head is accompanied with a sort of a stone throne to the right (Figure 12).

Russian archaeologists found many megalithic complexes on the river Iset, the Urals. Among them there is a place with two boulders looking like the heads of elks (Figure 14). According to Viktorova, V.D. there are no megalithic anthropomorphic figures on the monuments of the upper Iset River. Here, multi-ton figures made by ancient man are represented only by two images-an elk and a bear. As a rule, these were animal heads made in the so-called "stone style" (Viktorova, 2010: p. 108). According to Semenov, S.A. the "stone style" is formed when the natural boulders or slabs were chipped or cut, thus been given a new form, most often of sacred significance (Semenov, 1968: p. 238). 


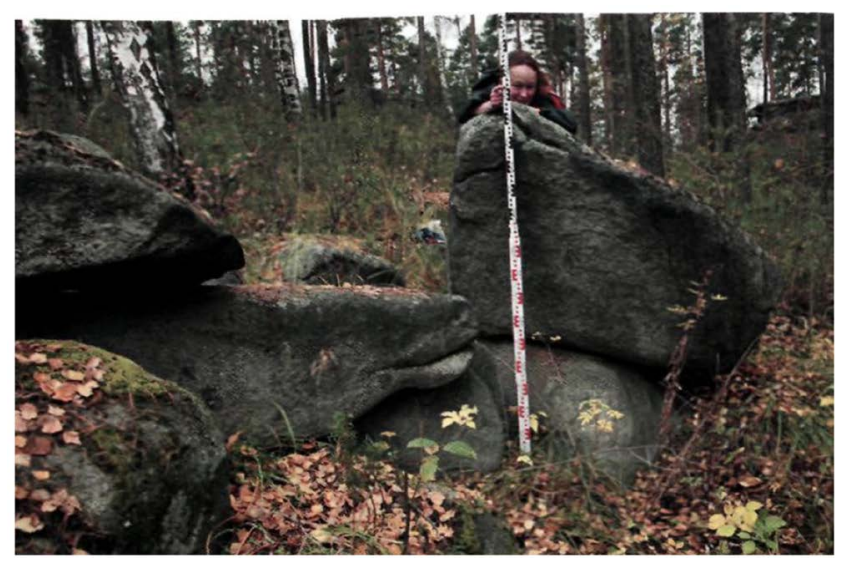

Figure 14. The megalithic construction with two stones in the shape of an elk/deer (Iset, the Urals, Russia) (Viktorova, 2010).

As it is reported by Russian archaeologists, since the beginning of the Holocene epoch, the images of the elk and the bear have become significant in the mythological world picture of the hunters from the forest belt of Eurasia. In the Meso-Neolithic drawings and petroglyphs of Northern Norway and Angara, the image of an elk dominated. An example of this is the bone pommels of wands in the form of an elk's head, found in the burials of persons of high social status at the Oleneostrovsky burial ground, which belong to the same time. On the Urals this image is presented in various materials: the pommels of the wands from the Shigirskii peat bog which are made of horn, and the ones from the Neolithic settlement of Evstyunikha made of stone. In the upper Iset River, at the Neolithic settlement of Isetskoe Pravoberezhnoye 1, a small flint sculpture in the form of an elk head was found (Viktorova, 2010: p. 108).

\section{Archaeological Data Revealing the Roots of Common Eurasian Cult Since the Paleolithic}

Archeological findings show the presence of identical artifacts found in different regions of Eurasia. This is not only the same ceramics, the same ornamental patterns, the same unique religious symbols on the pottery (Mironova, 2013), but also the stone artifacts, which were found recently on many archaeological sites. They are: double-sided (polyeiconic) zoomorphic pebbles, heart-like anthropomorphic images on the stones and mountains, corner anthropomorphic images (on the junction of two sides of a stone, a boulder or even a mountain). They all are spread across Eurasia, on different Paleolithic and Mesolithic settlements, from Brittany to the Far East (Mironova, 2017a). Gorshunova, O.V. considers that the caves were the places of the Great Goddess home in the consciousness of ancient people. According to her research, the cave shrines in the mind of primitive man were incarnations of the Goddess herself, which explains the mysterious behavior of primitive artists (Gorshunova, 2007: p. 23). According to Levy, G. the cave cavity could be perceived as the womb of the goddess, and the rites performed in it were a manifestation of the desire to join the acts of creation, in- 
cluding the birth of animals from its womb, which served as a means of maintaining the life of Paleolithic people (Levy, 1963).

Why stones and mountains were made sacral-this question was also addressed by Victorova, V.D. in 2010: "Can archaeologists answer the questions: are there any signs for distinguishing from a large number of mountains those ones that were revered as sacred, and what time does the sacralization of individual mountains belong to? Based on the ethnographic data, let's start with the answer to the first question. One of the signs is the location of the mountain near the reservoir of water, which is also revered as sacred (Gemuev \& Baulo, 1999). The second sign is the presence of rocks on the tops or slopes of the mountains and the unusual shape of the rocks. We will add to these features also those that are characteristic of the sanctuaries of the Upper Iset granite massif: the presence of platforms and the use of natural bowl or, if they were not, the creation of man-made ones" (Viktorova, 2010: p. 116).

In the previous chapter we pointed out the large stones which stood on the sacral places (they are still there) and which were found by the present-day archaeologists in Ukraine (in the Carpathian mountains) and in Russia (in the Urals). But as it happens always with the cult objects, worshippers want to have a particle of this sacral object for accompanying and protecting them everywhere. Present day small icons are the evidence of this religious tradition. Now we can point the time of originating this kind of tradition.

We managed to find the proof of a custom to take a particle of a cult object from the sacral area, rooted in the Paleolithic. It is a drawing on the wall of a world-known Altamira Cave (Spain), the entrance to which was blocked 12000 years ago. The replica of this cave is called Cova Nueva and it has every detail of the original cave restored and constructed in full compliance with the original. Thus we have noticed a strange drawing on the wall (Figure 15), which we decode as the precise technical and visual explanation of how to make an "icon" out of a big stone.

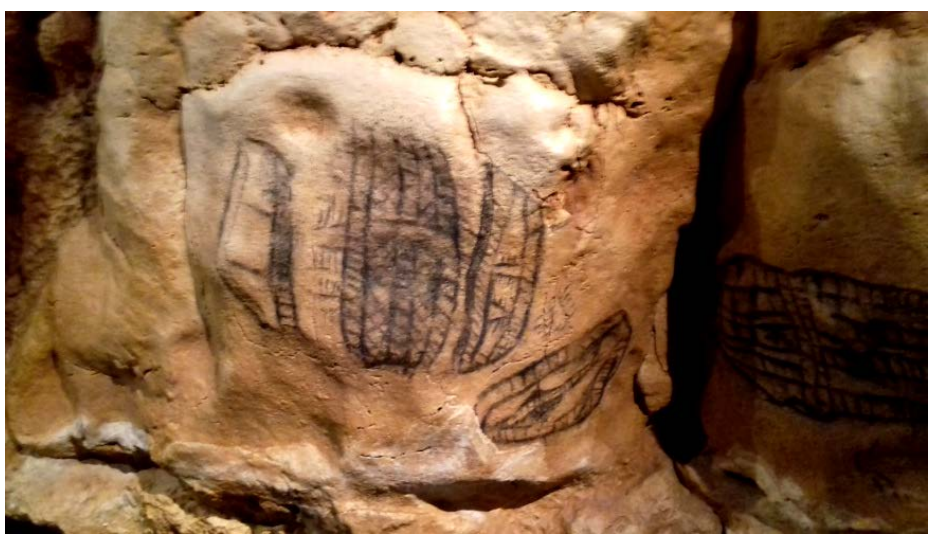

Figure 15. A fragment of geometric signs complex located on the convex part of the wall from the Altamira Cave (replica). This protruding part of the wall also has the features of an anthropomorphic image: symmetrically located recesses (perhaps "eyes" of an anthropomorphic face) (photo by Elena A. Mironova). 
The explanation of the drawing on the wall of the Altamira Cave (Figure 16), which we offered on the basis of numerous artifacts of a similar shape, found both in archaeological expeditions in excavations at different sites (Mesolithic-Neolithic) by Russian scientists over the past decade, and on the shores of the Sea of Azov and the Black Sea by the author of this article (Mironova, 2018) is as follows: there is a picture-an engineering drawing, a visual aid for masters of the Paleolithic period, in one of the halls of the cave, which served as a workshop for the production of religious objects and household tools, consecrated to give them strength. This engineering drawing conveys three angles of the blank stone (Figure 15). During its processing it was possible to get three sculptures (in this case). The image is made three-dimensional; the middle image shows the widest part of the stone, consisting of several layers (different types of stones). The right part is slightly distorted, as the stone has been damaged-it has broken off and the drawing no longer conveys the outline of the bear/elk (Figure 16(b)). The left part conveys the contours of the polyeiconic zoomorphic sculpture-bear-elk (Figure 16(a)). Horizontal strokes are the width of the chipped (desired) layer (Figure 17(b)). Criss-cross strokes show the layer that will be destroyed when the desired layer is separated (Figure 17(c)). The bottom right drawing (Figure 15 and Figure 16(c)) - this image shows the central part that will be best processed, since both of its surfaces will be flat.

Thus, this initial stone extracted from the cave wall (the "home of the Goddess" and her presentation) is designed for three sculptures. This assumption

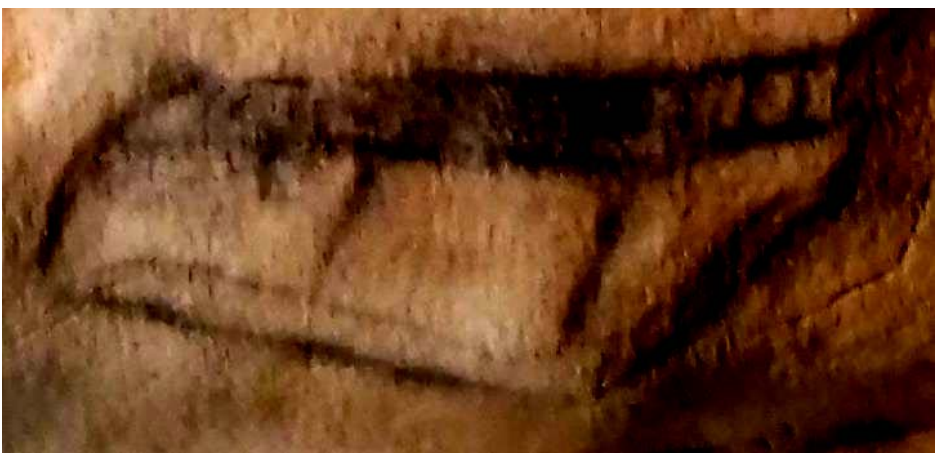

(a)

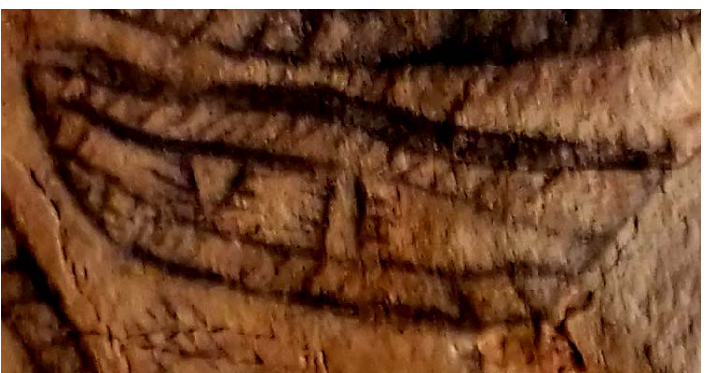

(b)

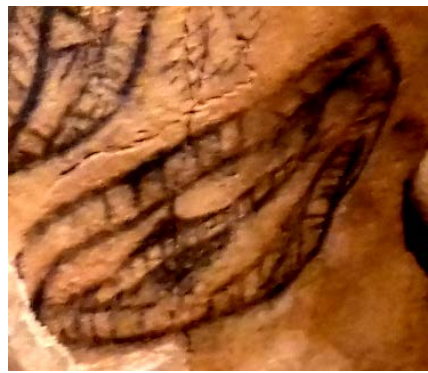

(c)

Figure 16. Three products that could be obtained from stone-blanks (polyeiconic zoomorphic sculptures). Charcoal drawings on the wall surface in the Altamira Cave (reconstruction) (photo by Elena A. Mironova). 
should also be tested using experimental methods: the selection of raw materials (it should be a sample with a multi-layered structure that is well amenable to splitting), the splitting process (it is necessary to reconstruct the method that was possible in the Upper Paleolithic), the final refinement of the shape of the resulting sculptures (a small grinding or retouching, since the sides of the raw stone shown in this Paleolithic engineering drawing, already had the desired shape). The final result is shown on the back side of the wall in Altamira Cave and it has similar shape, contour and parts as the artifact from Zamostie 2 site, Russia (Figure 18).

The side surfaces of these two artifacts (Figure 18) - one of which is an instrument (Lozovsky, 2014) the other one is a painting of an artifact (Mironova, 2018) look alike. Both of these artifacts are of the same shape and they have three segments clearly shown with the help of two vertical lines on the drawings. The striking fact is that the first drawing is the modern one and it depicts the real artifact from Zamostie (Upper Mezolithic layer) and the other is the ancient drawing from the Altamira Cave (not later than 12,000 years before present).

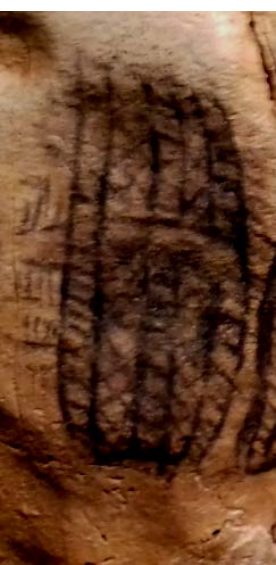

(a)

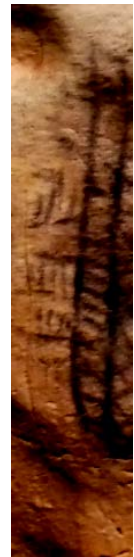

(b)

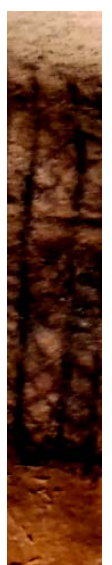

(c)

Figure 17. (a) General view of the initial stone-a blank for splitting and obtaining polyeiconic zoomorphic canonical cult sculptures; (b) a fragment showing the layer that was to be separated and was one of the future sculptures; (c) a fragment showing the layer marked by the artist-priest as an extra layer that was not needed for further processing and which was destroyed when the desired layer was separated (photo by Elena A. Mironova).

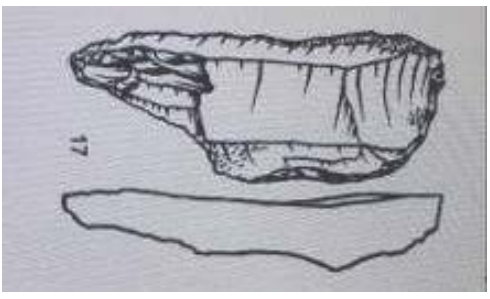

(a)

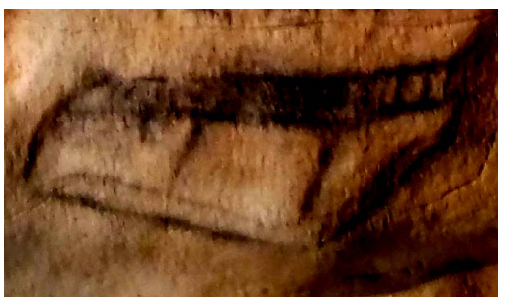

(b)

Figure 18. Comparison of two zoomorphic stone sculptures: (a) Zamostie 2 site. Flint industry of the Upper Mesolithic layer (Lozovsky, 2014: p. 275); (b) a drawing on the wall of Altamira Cave, Spain (Cova Nueva) (Mironova, 2018). 


\section{Conclusion}

After comparing the archaeological finds-the similar looking artifacts from many sites in Russia (the Urals, Siberia, the Sea of Azov and the Black Sea shores), we can state that all of them have the same shape irrespective of the size-from very small samples $(2.8 \mathrm{~cm}$ and $2.3 \mathrm{~cm})$ to the megaliths. The principle of their production in case with the pebbles is now obvious, after the discovery of a painting-drawing meaning (in the Altamira Cave) - a suitable stone with the layered structure was divided into three portions which were separated alongside. All three copies had one and the same shape: elongated on one side and wide on the opposite side. In case with the megaliths, the whole boulder of a suitable shape was either found among other boulders and then was processed to gain a necessary look or it was well suited from the very beginning. In many cases the purpose of these kinds of specially processed stones (from pebbles to boulders) remain enigmatic for the archaeologists (Bocharova \& Zotkina, 2017; Kovalenko, 2015) because these artifacts were not utilized as instruments and no any traces of their usage were revealed with the help of modern devices. So, their technological function has remained undiscovered since now.

Our study of the present-day data concerning suchlike man-made stone sculptures (heads of elk/deer) of different sizes-from the megaliths to the tiny pebbles, found in the sacral places in the mountains or on the seashores, from the Catalonian Coast (Costa-Brava) to the Urals and Siberia proves the existence of the common religious cult of Eurasia. This cult was devoted to the idea of fertility and worshipping stones as the representation of Great Goddess (a mountain which can provide a man with everything needed for life and survival: a refuge (a cave) and water supplied by it with three ways-from the springs, from the glaciers and from rain that comes from the clouds accumulated with this mountain.

Manifestation (markers) of this cult still exists and could be found not only in the archaeological sites (in stratigraphic layers), but also on the surfaces of very special (sacral) places. These sacral places or "sacral areas" as they are called in science, are near the mountains of a specific shape, on the borders of the soil and water (where two natural elements meet) and where shamans were buried, on the shallow beaches, where the ancient ceremonies of giving birth to children occurred, etc.

The new find which is described in this article and which was found on the shore of the Sea of Azov, in the Gulf of Taganrog (precisely, on Pavlo-Ochakovskaya spit) - a pebble in a shape of a deer/elk head-is one more evidence of this common cult. It has not only the similar shape, but also marks of intentional processing, namely, the eyes on both surfaces, the distinctly recognizable drawing of a running deer and an incision (straight line, performed with a help of a very acute edge of some tiny instrument) shaping the head of this running deer. This small pictured deer has also a tiny round eye (also performed either with a help of a dark paint or some kinds of contrasting material which left such signs on the 
light surface of this pebble).

This place (Pavlo-Ochakovskaya spit) has already provided another find-a zoomorphic pebble with an engraved figure of a standing man (Mironova, 2016) and there is an essential need for the science (anthropology, archaeology and paleontology) to continue investigating this site for other discoveries. We will be witnesses to something significant and very extraordinary.

\section{Conflicts of Interest}

The author declares no conflicts of interest.

\section{References}

Antonova, Yu. E., \& Tashak, V. I. (2013). Barun-Lamkhe-Ancient Sanctuary in Western Transbaikalia. Integratsiya arkheologicheskikh issledovanii = Integration of Archaeological and Ethnographical Investigations (Vol. 2, pp. 232-235). Irkutsk State Technical University.

Bartsyts, R. M. (2010). Abkhazian Religious Syncretism in Religious Complexes and Modern Ritual Practice (160 p.). Sukhum.

Bgazhnokov, B. H. (2016). Culture of Cup-Shaped Signs of Eurasia (82 p.). Publishing Department of KBIGI. http://www.kbigi.ru/fmedia/izdat/ebibl/znaki.pdf

Bocharova, E. N., \& Zotkina, L. V. (2017). Trasological Research of Plumbaginous Subject from the Settlement Kazachka-I. Studies of V (XXI) Russian Archaeological Congress, Vol. 1, 21-25. http://elibrary.asu.ru/xmlui/handle/asu/3896?show=full

Eliade, M. (1964). Les Sacré et le Profane. Gallimard.

Garkovik, A. V. (2013). Ancient Holy Places (a Case Study of Archaeological Sites in Primorye). In Archaeological and Ethnographical Investigations (Vol. 2, 310 p., pp. 172-177).

Gemuev, I. N., \& Baulo, A. V. (1999). Svyatilishcha mansi verkhov'ev Severnoy Sos'vy [Mansi Sanctuaries of the Upper Reaches of the Northern Sosva] (240 p.). Novosibirsk.

https://kronk.spb.ru/library/gemuev-baulo-1999.htm

Gimbutas, M. A. (1974). The Goddesses and Gods of Old Europe 7000-3500 BC: Myths, Legends and Cult Images. Thames and Hudson.

Gorshunova, O. V. (2007). Female Deity in the Religious and Worldview Representations of the Central Asian Peoples: An Abstract of the Dissert (50 p.). Doctor of Historical Sciences: 07.00.07. https://search.rsl.ru/ru/record/01003066719

Ivanov, A. V. (2011). Sacral Territories as Guardians of Traditional Values of the Eurasian Peoples (on the Example of the Ukok Plateau in the Altai and the Erdeneburen Valley in Western Mongolia). TUVA.Asia, New Research of Tuva, No. 4.

http://www.tuva.asia/journal/issue 12/4194-ivanov.html

Khasanova, Z. F. (2013). Attributes of Pre-Islamic Beliefs in Everyday Life and Economic Activity of the Bashkirs of the Inzer Basin. In Integration of Archaeological and Ethnographic Studies: Collection of Scientific Works (Vol. 2, pp. 147-150). Publishing House of IrSTU. https://www.elibrary.ru/item.asp?id=26858963

Klyosov, A. (2012). Ancient History of the Arbins, Bearers of Haplogroup R1b, from Central Asia to Europe, 16,000 to 1500 Years before Present. Advances in Anthropology, 2, 87-105. https://doi.org/10.4236/aa.2012.22010

Klyosov, A. A., \& Rozhanskii, I. L. (2012). Haplogroup R1a as the Proto-Indo-Europeans and the Legendary Aryans as Witnessed by the DNA of Their Current Descendants. Advances in Anthropology, 2, 1-13. https://doi.org/10.4236/aa.2012.21001 
Kotov, V. G. (2001). The Cult of Bear on the Urals According to the Data of Zapovednaya Cave. In Problems of Primitive Culture. Collection of Articles (pp. 86-105). Gilem.

Kovalenko, S. V. (2015). Monuments of Osinoozersky Neolithic Culture of the Left Cost of the Upper and Middle Amur. Russia and China: History and Prospects of Cooperation: Materials Y International Scientific and Practical Conference, Blagoveshchensk, 18-23 May 2015, 558 p.

Kugutyak, M. V. (2011). Starozhitnosti Hutsulshchini. Jerela $z$ etnichno istorii populennya Ukrainskikh Carpathian Mountains. Catalog of History and Culture Study (Vol. 1, 448 p.). Manuscript-Lviv.

Leroi-Gourhan, A. (1964). Les religions de la préhistoire. (Paléolithique). Presses Universitaires de France.

Levy, G. (1963). Religious Conceptions of the Stone Age. Harper \& Row.

Lidov, A. M. (2006). Hierotopy. The Creation of Sacred Spaces as a Form of Creativity and Subject of Cultural History. In A. Lidov (Ed.), Hierotopy. The Creation of Sacred Spaces in Byzantium and Medieval Russia (pp. 9-31). Indrik.

Lozovsky, V. M. (2014). Flint Industry of Mesolithic Layers of the Zamostie 2 Site. In G. A Khlopachev, \& S. A. Vasiliev (Eds.), Kamenny vek: Ot Atlantiki do Pacifiki: Zamyatninsky sbornik. Issue 3 (pp. 244-292). Russian Academy of Sciences, Museum of Anthropology and Ethnography.

http://kunstkamera.ru/files/lib/978-5-88431-251-7/978-5-88431-251-7 20.pdf

Mazhitov, N. A. (1977). The Southern Urals in the VII-XIV Centuries (239 p.). Nauka.

Medvedeva, G. V. (2011). Bear Cult and Its Reflection in the Oral Folk Prose of Russian OldTimers of Eastern Siberia: Semantics, Plot-Motive Fund of Narratives, Nominations 36 p.). Author's Abstract Dissertations for the Degree of Doctor of Philology.

Mellaart, J. (1965). Earliest Civilizations of the Near East. Thames and Hudson.

Mironova, E. A. (2013). Identical Pottery Shapes, Matching Ornaments, and Identical Signs on Artifacts from the Neolithic, Eneolithic, and Bronze Age Cultures of Europe, Asia, and North America (Comparison of Data by Culture: Cucuteni/Tripolye-Yangshao-Ban-Chang-Anasazi/Mogollion). Proceedings of the Academy of DNA Genealogy, 6, 267-374. http://dna-academy.ru/wp-content/uploads/6 2 2013.pdf

Mironova, E. A. (2015a). Complex Study of the Phenomenon of the Prevalence of the Image of a Bear in the Form of Pebble Sculptures on the Coasts of Eurasia. Academy of Trinitarism. http://www.trinitas.ru/rus/doc/0211/002a/02111145.htm

Mironova, E. A. (2015b). Two-Sided Zoomorphic Pebble Sculpture from the Black Sea Coast. Academy of Trinitarism. http://www.trinitas.ru/rus/doc/0211/002a/02111167.htm

Mironova, E. A. (2016). Zoomorphic Pebbles with Engraving from the Coast of the Sea of Azov. Eco-Potential, 3, 109-117. http://elar.usfeu.ru/bitstream/123456789/5730/1/110-118.pdf

Mironova, E. A. (2017a). Reasons of Steady Existence and Wide Spread of the Great Goddess Cult of Paleolithic in Eurasia. Eco-Potential, 3, 124-143. http://elar.usfeu.ru/bitstream/123456789/6640/1/eko 17-3 11.pdf

Mironova, E. A. (2017b). Stone Zoomorphic Sculpture from Croatia. Academy of Trinitarism. http://www.trinitas.ru/rus/doc/0211/002a/02111183.htm

Mironova, E. A. (2018). Research of Altamira Cave-The Source of Data about the Paleolithic Cult of Great Goddess. Eco-Potential. Quarterly Scientific Journal, 3, 127-147. http://elar.usfeu.ru/bitstream/123456789/7811/1/eko 3 2018 12.pdf

Mironova, E. A., \& Shkvarya, K. N. (2018) Reasons for the Wide Spread of the Protosyllable- ${ }^{*}$ kam-(and Its Phonetic Variants- ${ }^{*}$ kham-, ${ }^{*}$ cham-) in the Modern Place-Names (Multidisciplinary Approach). Advances in Anthropology, 8, 273-288. 
https://doi.org/10.4236/aa.2018.84011

Molodin, V. I., Oktyabrskaya, I. V., \& Chemyakina, M. A. (2000). Obraz medvedya v plastike zapadnosibirskikh aborigenov epokhi neolita i bronzy [The Image of a Bear in the Plastic of West Siberian Aborigines of the Neolithic and Bronze Age]. In I. N. Gemuev, N. A. Alekseev, \& I. V. Oktyabrskaya (Eds.), Narody Sibiri: Istoriya i kul'tura. Medved' $v$ drevnikh i sovremennykh kul'turakh Sibiri [Peoples of Siberia: History and Culture. The Bear in the Ancient and Modern Cultures of Siberia] (pp. 23-47). Publishing House of the Institute of Archeology and Ethnography SB RAS.

Okladnikov, A. P. (1966). Petroglyphs of the Angara (322 p.). Nauka.

Rybakov, B. A. (1981). Paganism of the Old Slavs. Nauka Publishing House.

Sadraei, A., Mehneh, M., Sheikh, M., Anani, B., \& Minaei, Z. (2019) Kaftar Kouh of Ferdous, New Evidence of Paleolithic Population in Southern Khorasan, Iran. Advances in Anthropology, 9, 111-123. https://doi.org/10.4236/aa.2019.92009

Semenov, S. A. (1968). Development of Technique in the Paleolithic (pp. 247-248).

Serikov, Yu. B. (2011). Novoe eneoliticheskoe pogrebenie s Shaitanskogo ozera (Sredneye Zauralie) (Vol. 26. pp. 145-150). Magellan Publishing House.

Serikov, Yu. B. (2012a). Cult Stones of the Middle Urals. In Regional History, Local History, Historical Local Lore in the Subject Fields of Modern Historical Knowledge (pp. 195-201). Publishing House: "Udmurt University".

Serikov, Y. B. (2012b). New Rock Shrines of the Shaitan Lake. Bulletin of the Perm University, 1, 38-49. https://elibrary.ru/item.asp?id=17704459

Serikov, Y. B. (2014). Essays on the Primitive art of the Urals (268 p.). Nizhny Tagil State Socio-Pedagogical University.

Sokolova, A. N. (2013). Sacred Places of Abkhazians and Adyghes as an Object of Scientific Research. The Bulletin of the Adyghe State University. Series 1: Regional Studies: Philosophy, History, Sociology, Jurisprudence, Political Science, Cultural Studies, 3, 3 p. http://cyberleninka.ru/article/n/svyaschennye-mesta-abhazov-i-adygov-kak-obekt-nau chnogo-issledovaniya-2

Viktorova, V. D. (2010). Riddles of the Upper Iset Granite Massif. Bulletin of the Ural Branch $R A S$, 4, 107-117. http://www.ihist.uran.ru/files/20104107-117.pdf 